\section{Surface Studies of Ultra Strength Drilling Steel after Corrosion Fatigue in Simulated Sour Environment}

\author{
M. Ziomek-Moroz ${ }^{\mathrm{a}}$, J.A. Hawk ${ }^{\mathrm{a}}$ \\ ${ }^{a}$ U.S. Department of Energy \\ National Energy Technology Laboratory \\ 1450 Queen Avenue SW, Albany, OR 97321, USA
}

\author{
T. Ramgopal ${ }^{\text {b }}$, F. Gui ${ }^{\text {b }}$ \\ ${ }^{b} \mathrm{DNV}$-Columbus \\ 5777Frantz Road \\ Dublin, OH-433017Park, PA 16802, USA
}

The Unites States predicted 60\% growth in energy demand by 2030 makes oil and natural gas primary target fuels for energy generation. ${ }^{1}$ The fact that the peak of oil production from shallow wells ( $<$ $5000 \mathrm{~m}$ ) is about to be reached, thereby pushing the oil and natural gas industry into deeper wells. However, drilling to depths greater than $5000 \mathrm{~m}$ requires increasing the strength-to weight ratio of the drill pipe materials. Grade UD-165 is one of the ultra- high yield strength carbon steels developed for ultra deep drilling (UDD) activities.

Drilling UDD wells exposes the drill pipes to $\mathrm{Cl}^{-}$, $\mathrm{HCO}_{3}{ }^{-} / \mathrm{CO}_{3}{ }^{2-}$, and $\mathrm{H}_{2} \mathrm{~S}$-containig corrosive environments (i.e., sour environments) at higher pressures and temperatures compared to those found in conventional wells. Because of the lack of synergism within the service environment, operational stresses can result in catastrophic brittle failures characteristic for environmentally assisted cracking (EAC). ${ }^{2}$ Approximately $75 \%$ of all drill string failures are caused by fatigue or corrosion fatigue. Since there is no literature data on the corrosion fatigue performance of UD-165 in sour environments, research was initiated to better clarify the fatigue crack growth (FCGR) behavior of this alloy in UDD environments. ${ }^{3}$

The FCGR behavior of ultra-strength carbon steel, grade UD-165, was investigated by monitoring crack growth rate in deaerated $5 \% \mathrm{NaCl}$ solution buffered with $\mathrm{NaHCO}_{3} / \mathrm{Na}_{2} \mathrm{CO}_{3}$ and in contact with $\mathrm{H}_{2} \mathrm{~S}$. The partial pressure of $\mathrm{H}_{2} \mathrm{~S}$ ( $\mathrm{p}_{\mathrm{H} 2 \mathrm{~S}}$ ) was $0.83 \mathrm{kPa}$ and $\mathrm{pH}$ of the solution was adjusted by $\mathrm{NaOH}$ to12. The fatigue experiments were performed at 20 and $85^{\circ} \mathrm{C}$ in an autoclave with surface investigations augmented by scanning electron microscopy (SEM) and energy dispersive x-ray (EDX) spectroscopy. In this study, research focused on surface analyses supported by the fatigue crack growth rate measurements. Fig. 1 shows an SEM micrograph of the crack that propagated from the notch in the solution at $20^{\circ} \mathrm{C}$. Accumulation of the corrosion products is visible along the crack. The EDX chemical analysis near the crack tip found iron, sulfur and oxygen in the passive layer.

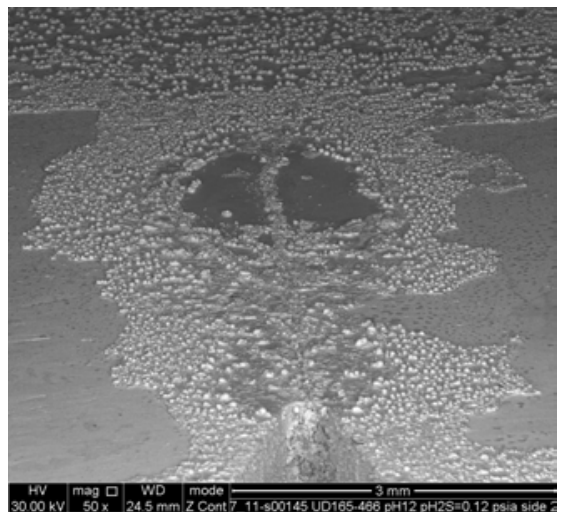

Fig. 1. SEM micrograph of UD-165 after a fatigue test in $\mathrm{NaCl} / \mathrm{NaHCO}_{3} / \mathrm{Na}_{2} \mathrm{CO}_{3} / \mathrm{p}_{\mathrm{H} 2 \mathrm{~S}}=0.83 \mathrm{kPa}$ at $20^{\circ} \mathrm{C}$.

The surface of the sample after the fatigue test in the sour environment at $85^{\circ}$, Fig. 2, C looks different from that fatigued surface at $20^{\circ} \mathrm{C}$.

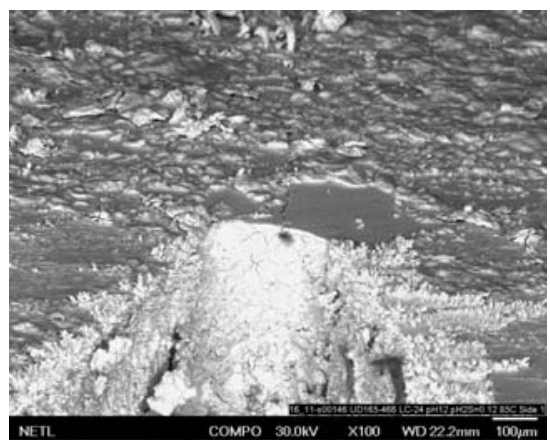

Figure 2. SEM micrograph of UD-165 after a fatigue test in $\mathrm{NaCl} / \mathrm{NaHCO}_{3} / \mathrm{Na}_{2} \mathrm{CO}_{3} / \mathrm{p}_{\mathrm{H} 2 \mathrm{~S}}=0.83 \mathrm{kPa}$ at $85^{\circ} \mathrm{C}$.

The crack propagates across the passive film that covers the surface fairly uniformly. Some spallation of the passive film is observed near the notch. The EDX chemical analysis of the passive film near the crack tip identified mainly iron, carbon and oxygen.

It appears that temperature plays a very important role in formation of the passive film. This may be associated with different solubility of $\mathrm{H}_{2} \mathrm{~S}$ in the solution, which will be further studied.

References:

1. S.A. Holditch, R.R. Chianelli, MRS Bulletin, 33 (2008), p.317

2. M. Ziomek-Moroz, J. of Materi. Eng. and Perform. DOI: 10.1007/s11665-011-9956-6

3. T. Ramgopal, F. Gui, J. Hawk, M. Ziomek-Moroz, Corrosion 2011, Paper no. 11108 